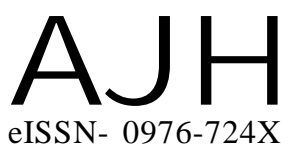

Received : 09.06.2016

Revised : 07.10.2016

Accepted : 21.10.2016

Members of the Research Forum

Associated Authors:

${ }^{1}$ Department of Horticulture,

Mahatma Phule Krishi Vidyapeeth,

Rahuri, AHMEDNAGAR (M.S.) INDIA

Author for correspondence : DINAR S. PATIL

Department of Horticulture,

Mahatma Phule Krishi Vidyapeeth,

Rahuri, AHMEDNAGAR (M.S.) INDIA

Email : dinar_2007@rediffmail.com
THEASIAN JOURNALOF HORTICULTURE

Volume 11 | Issue 2 | December, 2016 | 280-287

Visit us -www.researchjournal.co.in

\title{
Inheritance of fruit yield and its components in muskmelon (Cucumis melo L.)
}

\section{DINAR S. PATIL, A.M. MUSMADE ${ }^{1}$ AND H.K. SHIRSATH ${ }^{1}$}

ABSTRACT : Six generation $\left(\mathrm{P}_{1}, \mathrm{P}_{2}, \mathrm{~F}_{1}, \mathrm{~F}_{2}, \mathrm{~B}_{1}\right.$ and $\left.\mathrm{B}_{2}\right)$ means of five crosses obtained by crossing five inbreeds of muskmelon were used to study the inheritance of fruit length, fruit diameter, pulp thickness and fruit weight. In most of the crosses, the relative contribution of dominance gene action was higher than additive gene action. Epistasis interactions also played a prominent role in majority of interacting crosses for all studied characters. Heterosis breeding is suggested for the improvement of fruit traits in muskmelon.

KEY WORDS : Inheritance, Additive gene, Dominance, Epistasis gene action, Gene effects

HOW TO CITE THIS ARTICLE : Patil, Dinar S., Musmade, A.M. and Shirsath, H.K. (2016). Inheritance of fruit yield and its components in muskmelon (Cucumis melo L.). Asian J. Hort., 11(2) : 280-287, DOI : 10.15740/HAS/TAJH/11.2/280-287. 